\title{
Current Insight into Anti-HPV Immune Responses and Lessons for Prophylactic and Therapeutic Vaccines
}

\author{
Isabelle Bourgault-Villada ${ }^{1,2}$ and Simon Jacobelli² \\ ${ }^{1}$ AP-HP, Hôpital Ambroise Paré, Boulogne Billancourt, UVSQ, Versailles, \\ 2Institut Cochin, Paris, Université Paris Descartes
}

France

\section{Introduction}

Human Papillomavirus (HPV) are epitheliotropic for stratified malpighian epithelia such as those of the cervix, vulva or anal canal. Mucosal papillomaviruses are responsible for several clinical lesions and can be classified as non oncogenic and oncogenic viruses. The first ones are responsible for benign lesions such as external genital warts (EGW) or condyloma due to HPV 6 and 11. The second ones include oncogenic viruses such as HPV 16 and 18, the most common ones, and HPV 45, 31, 33, 52 etc which are involved in invasive cancers preceded by cervical, vulvar, penile or anal intraepithelial neoplasia. Oncogenic HPV are detectable in $99.7 \%$ of cervical cancers (Bosch et al, 1995). Cellular immunity plays a key role in controlling and killing infected or transformed keratinocytes. Nevertheless, around $10 \%$ of women having infected cervical mucosa are not able to control oncogenic HPV and develop cervical intraepithelial neoplasia (CIN). High grade CIN (CIN3) require surgical treatment before their progression to invasive cancers in $30 \%$ of cases (McCredie et al, 2008; Ostor et al, 1993). A great priority is then to develop a preventive vaccine to protect against HPV infection. In women with CIN, therapeutic vaccine could be used to eliminate previously infected or transformed keratinocytes and avoid surgical treatment.

\section{Virology}

Following a breach in the malpighian pluristratified epithelium, HPVs infect basal stem cells of keratinocytes. The virus initially remains in episomal form with synthesis of E2 protein. This protein is a major regulator of viral vegetative cycle and is required for transcriptional regulation as well as viral DNA replication together with the E1 helicase (Desaintes et al, 1996). In contrast, E2 is generally undetectable in cancers due to a preferential integration of the viral genome in the cell genome and disruption of the E2 open reading frame (Berumen et al, 1994; Collins et al, 2009). Therefore E2 is a marker of viral infection and is specific for the early stages of the viral gene expression in infected cells. This was formally demonstrated in a recent work that showed a strong staining of the E2 protein in the intermediate differentiated layers of HPV16-infected tissues and low grade CIN (Xue et al, 
2010). The high expression of HPV16 E2 in low grade lesions therefore represents a marker for HPV infection even before any clinical manifestation.

After integration of the genome of oncogenic HPVs into the host genome, viral oncogenic E6 and E7 proteins are synthesized in large quantities in the inner third of the epithelium. During maturation of keratinocytes from the basal layer to the epithelial surface, viral capside proteins L1 and L2 are synthesized and expressed at the surface of mature keratinocytes in order to form a new viral particle which is able to infect adjacent healthy epithelium and to contaminate sexual partners.

\section{Epidemiology of oncogenic HPV and related diseases}

HPV infections occur preferentially in young women under 25 years of age (Boulanger et al, 2004). Several stages of lesions can be observed following oncogenic HPV infection. The first stage is a simple infection of keratinocytes that become koilocytes and develop into condyloma. The following stages are related to the transformation of infected keratinocytes into malignant cells. The depth at which malignant cells are found defines the disease stage: low (as CIN1) or high grade squamous intraepithelial lesions as CIN2/3. The latter is diagnosed on the basis of Pap smears, followed by colposcopy and biopsies and can evolve towards invasive cancer. HPV16 is found in more than $50 \%$ of cervical cancer cases and HPV18 in 17\%. The incidence of cervical cancer remains very high with 500000 new cases per year in the world, essentially in developing countries where the level of screening by Pap smear is very low. It annually leads to 230000 deaths.

The premalignant lesions of HPV-related grade 3 usual vulvar intraepithelial neoplasia (usual VIN or VIN3) involve the mucosal and/or cutaneous epithelium of the vulva, perineal and perianal region. Usual VIN occurs in adult women and commonly resembles persistent anogenital warts that are often multifocal pigmented papular lesions disseminated on the vulva and/or the perianal skin. Usual VIN is characterized by the presence of poorly differentiated or undifferentiated basal cells and highly atypical squamous epithelial cells (McClugagge et al, 2009). The oncogenic HPV most frequently found in usual VIN is HPV16 that plays a direct role in up to $91 \%$ of the cases (Srodon et al, 2006).

The overall incidence rates of anal cancer has recently increased, particularly among men who have sex with men (MSM) and HIV-infected patients (Piketty et al, 2008) Combination antiretroviral therapy does not prevent nor revert anal cancer in the latter patients (Piketty et al, 2010). Despite several HPV coinfections in particular in HIV-infected patients, HPV16 is the most common one in anal cancer (Abramowitz et al, 2011).

\section{Humoral immune response after HPV infection}

Serum antibodies against HPV are directed against viral capside antigens and in particular against L1 protein. Their synthesis is late (6 to 12 months after infection) and antibody concentration remains limited because of the absence of HPV viremia (Carter et al, 2000). However, these antibodies persist in many women for at least 10 years (af Geijersstam et al, 1998). Only 70\% of women having persistent HPV16 DNA in the genital 
mucosa have detectable antibodies (Ho et al, 2004; Kirnbauer et al, 1994). These antibodies do not play any neutralizing role against HPV after virus entry in basal stem cells of keratinocytes (de Gruijl et al, 1999) because L1 protein is not expressed at the surface of these cells.

\section{Antibodies detected after HPV infection do not protect against a new infection}

Antibodies synthesized after HPV infection do not protect against a new infection with the same HPV genotype, as observed in a cohort study of women with and without such antibodies (Viscidi et al, 2004, 2005). There was no difference over time between the two groups with respect to HPV16 DNA detection in the genital mucosa. This is not surprising since the level of the anti-HPV antibodies found in mucosal secretions is lower than in the serum where the level of antibodies is already very low (Lowe et al, 1997; Nardelli-Haefliger et al, 2003). Local secretory IgA could not stop the spread of HPV infection (Bard et al, 2004).

\section{Cellular immune response after HPV infection}

Cellular immune responses play a critical role in HPV infections by controlling or eliminating the virus. The incidence of HPV-induced diseases is increased in T-cell immunodeficient individuals, such as HIV-infected (Sun et al, 1997), transplanted patients (Arends et al, 1997), patients treated by immunosuppressive drugs (Ulrich et al, 2008) or in primary immunodeficiencies (Lawrence et al, 2005). In patients with high-grade CIN 2/3 or invasive cervical carcinoma, blood cytotoxic T lymphocytes (CTL) directed against HPV-16 E6 or E7 proteins are barely detectable (Nakagawa et al, 1997, 2000). Proliferative responses of CD4-lymphocytes against these two proteins seem to correlate with the infection stage. Indeed, high frequency specific interleukin-2 (IL2)-producing CD4 lymphocytes have been observed in asymptomatic HPV-16-infected women (de Jong et al, 2002) whereas they decrease during disease progression toward high-grade CIN or invasive cancer (Tsukui et al, 1996).

In a woman who completely cleared usual vulvar intraepithelial neoplasia (VIN) lesions eight months after disease onset (Figure 1), an immunohistochemical study showed a marked dermal infiltrate containing a majority of CD4+ T lymphocytes and an epidermal infiltrate made up of both $\mathrm{CD}^{+}$and $\mathrm{CD} 8^{+} \mathrm{T}$ cells (Figure 2) (Bourgault Villada et al, 2004). Before clinical regression, high frequency anti-E6 and anti-E7 effector blood T-cells by ex vivo IFN $\gamma$ ELISPOT assay was evidenced (Figure 3). This appears to be the first evidence of an association between spontaneous regression of usual VIN lesions and HPV-specific T cell responses detectable in the blood. Hence, an increase of HPV-specific effector T lymphocyte responses by vaccine-based therapeutic strategies might be useful to clear the lesions in usual VIN disease.

On the contrary, in chronic nonregressive CIN3, lymphocyte infiltrates in the epidermis mainly contain CD8+ lymphocytes and no CD4+ cells. It is likely that CD8+ lymphocytes play a major role in the defense against HPV infections by killing infected keratinocytes. However, CD4+ lymphocytes that synthesize IFN $\gamma$ and IL2 are required for an optimal induction of high affinity tumor-specific memory CD8+ effector T-cells. 


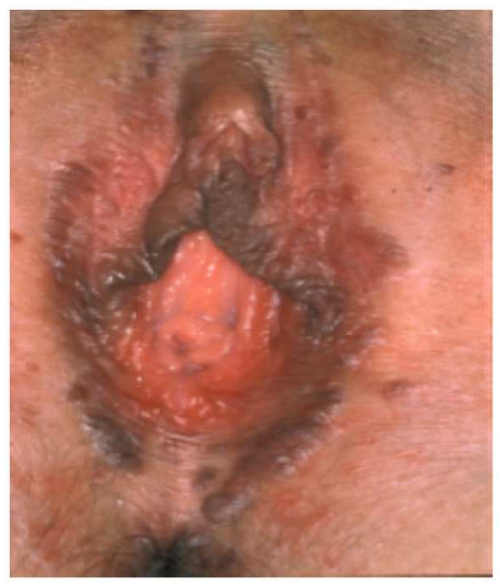

Fig. 1. Clinical lesions of multifocal pigmented usual VIN before spontaneous clinical regression

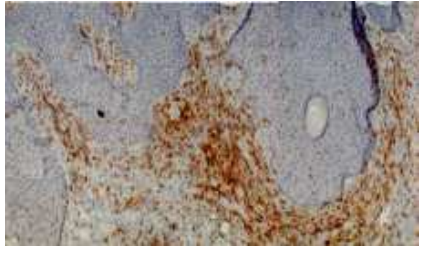

CD3 lymphocytes

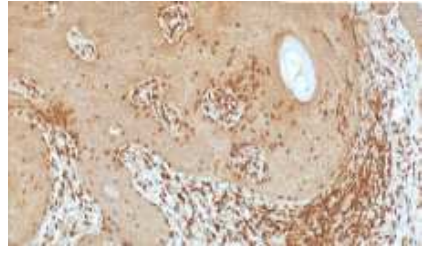

CD4 lymphocytes

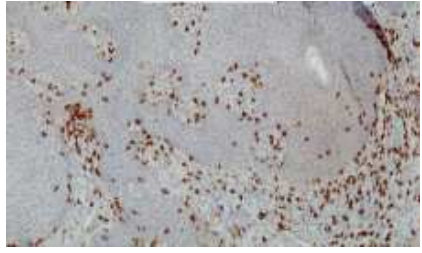

CD8 lymphocytes

Fig. 2. Immunohistochemical study of the vulvar biopsy just before spontaneous regression

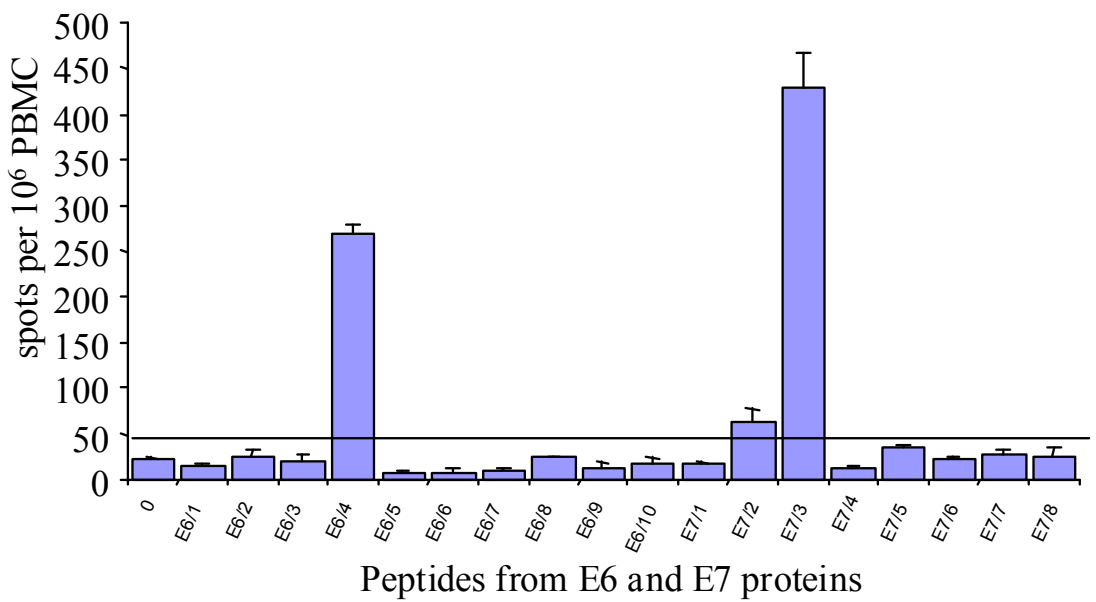

Fig. 3. IFN $\gamma$ ELISPOT assay performed just before clinical regression 


\section{Presentation of HPV antigens to T and B lymphocytes after HPV infection}

During infection, viral particles enter through epithelium up to basal basal stem cells of keratinocytes and sometimes can penetrate into the chorion. In the epithelium, they can be captured by Langerhans cells and they are quickly internalized (Bousarghin et al, 2005; Fausch et al, 2005; Malejczyk et al, 1997) and degraded into short and large peptides (Combadière et al, 2008; Herbst et al, 1996; Offringa et al, 2003; Yan et al, 2004). The classical view of the role of Langerhans cells is one of antigen uptake in the epidermis, and migration through the dermal lymphatics to the lymphoid organs, where they present antigen to lymphocytes that then home back to the tissue to carry out their effector function. Matthews et al (2003) have previously reported that Langerhans cells number is significantly reduced in HPV16 lesions without Langerhans cells depletion in the surrounding uninfected tissue. During HPV infection, the migration of Langerhans cells towards mucosal follicle is followed by presentation of short and large viral peptides by HLA class I and HLA class II molecules to CD4+ and CD8+ $\mathrm{T}$ lymphocytes, respectively. After stimulation, CD4+ and CD8+ T lymphocytes can circulate and migrate within the HPV-infected epithelium by using their surface molecules such as cutaneous lymphocyte antigen (Grover et al, 2006). The presentation of whole viral particles to B lymphocytes requires that HPV binds to dermal dendritic cells that are able to carry the whole virus to follicular dendritic cells present in mucosal follicle (Palucka et al, 2010).

\section{Does a T-cell marker of viral control exist?}

We recently tested by proliferative assays, intracellular cytokines synthesis and IFN $\gamma$ ELISPOT the cellular immune responses against the HPV16 E2 protein that is early synthesized after HPV infection when the virus is episomal in eight women presenting with HPV16-related usual VIN and their healthy male partners (Jacobelli et al, 2011, unpublished data). We showed that anti-E2 polyfunctional CD4 T-cell responses (proliferative responses and synthesis of IFN $\gamma$ and/or IL2) appear when the clinical lesions heal or when the HPV infection remains silent. Blood proliferative T-cell responses against HPV16 E2 peptides have been also observed in $50 \%$ of healthy women, who presumably previously cleared HPV16 infection (de Jong et al, 2004) and in 9 out of 22 regressive CIN3 cases (Dillon et al, 2007). In another studies, the lack of anti-E2 proliferative responses was reported in 16 of 18 patients (89\%) affected with usual VIN lesions (Davidson et al, 2003) and in 7 of 8 and 9 of 12 women affected with CIN3 (Dillon et al, 2007; de Jong et al, 2004). These observations reinforce the strong role of T-cells in the control of HPV replication.

\section{Why the male partners of women having CIN3 or usual VIN do not have any lesion?}

Men are vectors of oncogenic HPV infection (Buckley et al, 1981). However, while HPV infection was found in 71 to $90 \%$ of the partners of HPV-infected women (Hippelainen et al, 1994; Nicolau et al, 2005), only 52\% harbored the same HPV subtypes (Reiter et al, 2010). Moreover, penile intra-epithelial neoplasia is rare and detected in less than $2 \%$ of the men in contact with oncogenic HPV (Giraldo et al, 2008). We thus analyzed HPV infection and antiHPV16 E2 blood T-cell responses in asymptomatic male partners chronically exposed to HPV16 during sexual intercourses with their wives affected with usual VIN (Jacobelli et al, 
2011, , unpublished data). We had hypothesized that male partners exposed to replicative HPV16 could develop immunologic responses against the early E2 viral protein and thus clear infection. We indeed observed HPV16-E2-specific proliferative responses and intracellular synthesis of single IFN $\gamma$, dual IFN $\gamma /$ IL2 and single IL2. These T-cell responses indicate a striking link between the absence of HPV-related lesions and the presence of spontaneous anti-E2 specific polyfunctional T-cell response in male partners. It is tempting to speculate that E2-specific responses prevent HPV16-related lesions. Since E2 protein is not encapsidated in the viral particle, the strong E2-specific T cells responses measured in partners of women with usual VIN demonstrates that the virus effectively replicates in males. Our results suggest that male are an important reservoir of genital HPVs and provide a strong argument in favor of prophylactic HPV vaccination of young men with Virus Like Particles to decrease HPV16 infection in men, and thus fight against the spread of mucosal HPV diseases in the population.

\section{Balance between cellular immunity and infected / tumoral cells: Mechanisms of tumor escape}

The impairment of HPV-16-specific CD4 lymphocytes and CTL responses can occur many years after infection / transformation of keratinocytes. It could be related to the tumor or to T-cell responses. The tumor cells can down-regulate their MHC class I molecules, synthesize TGF $\beta$ or decrease the number of viral peptides on their surface. Mechanisms of T-cell tolerance to HPV includes presence of regulatory T-cells (Treg) at proximity of the tumor cells (van der Burg et al, 2007) and sometimes in the blood (Molling et al, 2007; Visser et al, 2007), engagement of PD1 or CTLA4 in the immune synapse and inhibition of CD3 zeta expression on infiltrating tumor T-cells (Patel et al, 2009; Zehbe et al, 2006).

\section{Prophylactic vaccines can prevent infection}

The vaccination against HPV can have two different purposes. The first one is a preventive strategy aiming at blocking primary infection by preventing the entry of the virus into their target cells i.e. the basal basal stem cells of keratinocytes. In this aim, a vaccination able to induce transudated serum antibodies at the epithelial surface is a good strategy and is obtained by using viral L1 particles as vaccine. Large quantities of L1 are produced in vitro by splicing the L1 gene into plasmids (for expression in yeast) or recombinant baculoviruses (for expression in insect cells). The Virus Like Particle is formed by self aggregation of 72 L1 capsomers into a sphere. This spherical structure is similar to the viral capside, but it is empty without DNA or RNA and non infectious. After systemic immunization, it is able to induce the synthesis of neutralizing antibodies that can recognize the conformational structure of the real viral capside. Inversely, after HPV infection, antibodies are ineffective and only therapeutic vaccines can be considered to induce T lymphocytes able to kill HPV infected keratinocytes. These therapeutic vaccines must target oncogenic E6 and E7 viral proteins early expressed in the basal epithelial cells.

Merck has developed Gardasil@, a vaccine directed against four HPV types. It contains Virus Like Particles (L1) from HPV-6, 11, 16, and 18, with aluminum hydroxyphosphate as an adjuvant. Cervarix ${ }^{\circledR}$ is a bivalent vaccine developed by GSK. It targets HPV-16/18 VLP (L1) and contains a novel adjuvant named ASO4 co-formulated with aluminum. ASO4 contains phospholipids from Salmonella minnesota membrane and binds to TLR4 at the 
surface of dendritic cells. Activated dendritic cells synthesize type I IFN, IL6, IL12, TNF $\alpha$ that allows recruitment and stimulation of Th follicular cells that increase antibodies production by B lymphocytes. Both vaccines must be administrated by intramuscular route. Three injections should be performed, at M0, M2 and M6 for Gardasil@ and M0, M1 and M6 for Cervarix ${ }^{\circledR}$. Gardasil ${ }^{\circledR}$ and Cervarix ${ }^{\circledR}$ have been commercialized worldwide and each country should define their own recommendations.

Phase I trials of Gardasil ${ }^{\circledR}$ were performed with only HPV16 L1 VLP in 30016 to 23 years old women, who had less than 5 sexual partners and had never been exposed to HPV16 (Harro et al, 2001). The immunogenicity of the vaccine was excellent with the induction of very high levels of blood anti-L1 antibodies, 50 to 100 times those observed after natural HPV infection. The tolerance of the vaccine was good with only a slight pain, swelling and erythema at the injection sites. Phase II trials included about 2000 subjects, they showed preliminary proof of efficacy using also HPV16 VLP versus a placebo (Koutsky et al, 2002). Subsequent phase III trial were carried out on more than 25000 subjects, using the quadrivalent vaccine containing VLP from HPV 6, 11, 16 and 18.98 to $100 \%$ protection was obtained against HPV -6, 11, 16, and 18 related diseases such as CIN2/3, vulvar and vaginal condyloma, usual VIN and VaIN3 (Garland et al, 2007; Joura et al, 2007; Munoz et al, 2010). Protection against persistent infection (for 6 months) by HPV16 or 18 was obtained in 99\% of cases. Gardasil® obtained an FDA approval for the vaccination of girls and women aged 9 to 26 years to prevent cervical cancer, precancerous genital lesions and genital warts. Recently, 90\% protection was obtained against extragenital warts in males (Giuliano et al, 2011). Efficacy of Gardasil@ obtained against HPV31-induced CIN2/3 is around $55 \%$. Finally, $43 \%$ protection was obtained against CIN2/3 induced by 14 oncogenic and non oncogenic genotypes of HPV (HPV 6, 11, 16, 18, 31, 33, 35, $39,45,51,52,56,58,59) 3.7$ years after vaccination.

As for Cervarix ${ }^{\circledR}$, phases I and II (Harper et al, 2004, 2006) studies showed 98 to $100 \%$ protection against CIN 2/3 similar to that of Gardasil@. The phase III trial involved more than 20000 subjects (Paavonen et al, 2007) and was approved by the FDA and European Medical Agency. 70\% protection was obtained against CIN2/3 related to 14 oncogenic HPV genotypes (HPV 16, 18, 31, 33, 35, 39, 45, 51, 52, 56, 58, 59, 66, 68) 3 years following vaccination (Paavonen et al, 2009). The efficacy of Cervarix ${ }^{\circledR}$ against HPV31-induced CIN2/3 is around $92 \%$. Protection against persistent infection (for 6 months) by HPV33 and 45 was obtained in 76 and $77 \%$ of cases respectively.

Nevertheless, many questions remain unanswered. How long will the protection last? Does thresholds of antibodies exist to allow the protection ? What will be the impact of the vaccination on the ecology of other HPVs, HPV screening by Pap smears and on adolescent sexual behavior and their use of condoms for HIV protection ? Will parents, preteens, physicians and the public at large, accept vaccination of young girls? Will it be interesting to vaccinate young men to decrease HPV16 infection in men, viral transmission from men to women and more importantly spread of mucosal HPV diseases in the population ? Are MSM the future candidates for vaccination against anal cancer?

\section{Protection by the quadrivalent prophylactic vaccine against cutaneous external genital warts}

A paradox exits between the protection by prophylactic vaccines against cutaneous EGW (related to HPV6 and 11 replicative viruses) and the absence of detectable antibodies on the 
keratinized skin surface. Following a breach in the epithelium, HPVs bind via L1 first to the basement membrane and then to the cellular receptor on the basal stem keratinocytes (Kines et al, 2009). Anti-L1 antibodies induced by prophylactic vaccines could block both of these interactions (Day et al, 2007). Indeed, this process of virus entry is slow, between 12 to 14 hours (Sapp et al, 2009) and, since the breach is accompanied by a serum exudate, exposure to serum antibodies is rapid. Another explanation for protection could be a stronger stimulation of anti-HPV CD4+ and CD8+ T-cells after infection. Indeed, in the presence of memory anti-L1 CD4+ T-cell, the CD8+ cytotoxic T-lymphocytes could be more strongly stimulated, with multiple specificities and higher affinity (Sauzet et al, 1995). The killing of infected keratinocytes could be then more effective.

\section{Prevention of infection by other oncogenic HPVs by divalent prophylactic vaccine}

Recently, it has been demonstrated that Cervarix ${ }^{\circledR}$ is able to prevent CIN2/3 induced by HPV 16 and 18 and also by HPV 31, 33 and 45 (http://www.ema.europa.eu/, cervarix®, summary of product characteristics). An efficacy of $70 \%$ and $43 \%$ was obtained against CIN2/3 related to 14 oncogenic HPVs $(16,18,31,33,35,39,45,51,52,56,58,59,66,68)$ with Cervarix ${ }^{\circledR}$ and 12 oncogenic HPVs $(16,18,31,33,35,39,45,51,52,56,58,59)$ with Gardasil@, respectively (http://www.ema.europa.eu/, gardasil@, summary of product characteristics). A high level of anti-HPV antibodies usually correlates with a broad recognition of B-cell epitopes. Such epitopes can be shared by several other closely related HPVs. In Cervarix ${ }^{\circledR}$, the use of ASO4 adjuvant allows to obtain high anti-HPV16 and 18 antibodies levels, that are able to prevent infection by numerous other oncogenic HPVs (McKeage et al, 2011).

\section{Alternative to L1 VLP vaccines}

A particularly attractive strategy is to vaccinate with a linear $\mathrm{N}$-terminal highly conserved sequence of the viral capsid L2 protein. In a properly immunogenic context, neutralizing antibodies to this $\mathrm{B}$ cell epitope-containing region are elicited and they have broadly neutralizing capacities against a wide range of HPVs (Conway et al, 2011). Immunization with adjuvanted chimeric HPV16L1-HPV16L2 VLP have also induced neutralization or cross-neutralization of HPV16, -18, -31, -45, -52, and -58; HPV6 and -11; and HPV5 (Schellenbacher et al, 2009). These new types of vaccine are very promising.

\section{How to cure infection / tumorigenesis? Therapeutic vaccines}

Preventive vaccines do not address the current need for better treatment for women previously infected by HPV 16 or 18. Other types of vaccines must be used to increase or induce new specific anti-HPV cellular immunity (CD4+ and CD8+ T lymphocytes) in order to kill transformed epithelial cells. Several approaches can be used in this aim. To stimulate cytotoxic or antiviral CD8+ T lymphocytes, the vaccines must target the cytoplasm of dendritic cells. The degradation of vaccine antigens by proteasomes results in short peptides that can bind to HLA class I molecules and migrate at the surface of dendritic cells. To stimulate CD4+ T lymphocytes, endocytosis of vaccinal antigens is essential, followed by degradation of antigens by lysosome/endosome in large peptides that associate with HLA 
class II molecules before migrating at the surface of dendritic cells. All these therapeutic vaccines must target E6 and E7 viral proteins and contain recombinant viruses (vaccinia viruses for example), DNA or peptides.

Peptidic or lipopeptidic vaccines were tested within phases I-II for treatment of women having CIN3 or metastatic cervical cancer. The chosen peptides were E7 11-20 and E7 86-93, two peptides able to bind HLA-A2 molecules in association with a CD4+ epitope (PADRE) able to bind numerous HLA-DR molecules (Ressing et al, 2000; Steller et al, 1998; van Driel et al, 1999). In women with invasive cervical cancer, 25 to $30 \%$ of cellular immune responses were observed without any clinical improvement. Another trial in 18 women with CIN3 has shown a clinical improvement in 50\% of them (Muderspach et al, 2000). Recently, an open clinical trial was performed by the Melief's group (Kenter et al, 2009) in twenty women presenting with usual VIN using 13 large peptides spanning the whole E6 and E7 proteins. Forty five percent of complete ( $9 / 20$ women) and $25 \%(5 / 20)$ of partial remission were observed 12 months after immunization. These important results would be even more interesting if the investigators had included a placebo group (Bourgault Villada, 2010a). A new trial with a placebo group is currently under way.

Vaccinia virus was used in a recombinant vaccine containing E6 and E7 genes from HPV16 and HPV18 (TA-HPV) to vaccinate usual VIN patients. A clinical complete or partial response was observed in 8/18 treated women (Davidson et al, 2003). More recently, vaccination against usual VIN was also performed with another recombinant vaccinia virus, TA-L2E6E7 from HPV16 (Daayana et al, 2010). Two months before vaccination, 19 women were treated by topical imiquimod and then vaccinated by intramuscular route with 3 doses of recombinant vaccinia virus. Imiquimod is an immunomodulator that increases the synthesis of type I IFN by dendritic cells after its fixation to the TLR7 in human dendritic cells. Complete remission was obtained in $58 \%$ of vaccinated women.

Vaccination against CIN 2/3 was also performed by Transgene using a recombinant vaccinia virus, MVA, associated with the genes coding for E6 and E7 proteins and IL2 cytokine in 18 women. The disappearance of the lesions was observed by colposcopy 6 months later in 10 patients, without any CIN at biopsy in 9 cases. The important conclusion of this trial was that the vaccine was clinically effective, thus avoiding conization for $50 \%$ of the women with HPV16-related CIN2/3. A phase II trial including a placebo group is presently undertaken.

A phase II clinical trial has also been performed to evaluate the potential use of the MVA-E2 in treating CIN 2/3 (Garcia-Hernandez et al, 2006). Thirty-four women received the therapeutic vaccine injected directly into the cervix once every week over a 6-week period. Nineteen patients (59\%) showed no lesion nine weeks later and histological analysis showed total elimination of high-grade lesions in 20 patients. All patients developed Ab against the MVA-E2 vaccine and showed a specific cytotoxic response against papilloma-transformed cells.

DNA containing E6 and E7 genes from HPV 16 and 18 (ZYC101a) was administered on 86 women having CIN2/3 (Garcia et al, 2004). Conization was performed 6 months later. Resolution of CIN was observed in $73 \%$ of the younger (less than 25 years old) women with a significant difference compared to a control group. This therapeutic vaccine is also very 
promising as CIN 2/3 treatment. New phase II trial is currently under way, testing DNA from E6 and E7 genes versus placebo.

All these results are very important and encouraging for the development of therapeutic vaccines for HPV induced cancers. Nevertheless the proof of efficacy in CIN 2/3 should be carefully demonstrated because therapeutic vaccine should be more efficient that surgery. It is important to note that these therapeutic vaccines should avoid relapse of HPV infection after treatment by increasing HPV-specific cellular immunity.

Other vaccines were tested to fight high grade anal intraepithelial neoplasia (AIN3) in HIV+ patients. HSPE7 including Mycobacterium bovis BCG heat-shock protein 65 (Hsp65) and HPV16 E7 protein was tested. Clinical complete and partial responses were observed in 5 vaccinated patients out of 15 (33\% of efficacy) (Palefski et al, 2006). A better vaccine with adjuvant is presently developed.

The safety and immunogenicity of the human papillomavirus type 16 (HPV16) or HPV18 (HPV16/18) E7 protein-pulsed mature dendritic cell vaccination (phase I) were evaluated as adjuvant therapy for 10 patients with stage IB cervical cancer treated by radical hysterectomy (Santin et al, 2008). All patients developed CD4+ T-cell and Ab responses to DC vaccination and 8 of them E7-specific CD8+ T-cells. DC vaccination was well tolerated and no significant toxicity was recorded. New trials (phase II) in cervical cancer patients harboring a limited tumor burden or who are at significant risk of tumor recurrence are warranted to show an efficacy of this immunotherapy.

Condyloma have been also treated by immunotherapy. Two trials were performed using the VLP of HPV6 (Zhang et al, 2000) or the fusion protein L2E7 fron HPV6 (Lacey et al, 1999; Thompson et al, 1999; Vandepapeliere et al, 2005) with a clearance of condyloma obtained in 75 and $20 \%$ of cases, respectively. In the absence of control group in these trials, it is too early to make conclusions about the efficacy of these vaccines. In a phase I/II trial, thirty males presenting with intraurethral flat condyloma were treated with either a recombinant vaccinia viral vaccine MVA-E2 (expressing the E2 gene of bovine papillomavirus) (Albarran et al, 2007). 28/30 patients treated with MVAE2 vaccine were free of clinical or histological lesion or HPV at 4 weeks.

\section{How to determine the epitopic regions for a therapeutic vaccine?}

In a study including 16 women presenting with usual VIN, we have determined the strongly immunogenic regions from HPV16 E6 and E7 proteins for CD4+ and/or CD8+ T lymphocytes (Bourgault Villada et al, 2010b). Among 18 large peptides of the proteins E6 and E7, two were recognized in proliferative assays as immunodominant by $\mathrm{T}$ cells from 10 out of 16 women (62\%) at the entry in the study, namely E6/2 (aa 14-34) and E6/4 (aa 45-68) peptides. Four other peptides, E6/7 (aa 91-110), E7/2 (aa 7-27), E7/3 (aa 21-40) and E7/7 (aa 65-87) were recognized by only $12 \%$ of the women in proliferative or IFN $\gamma$ ELISPOT tests. The regions of E6 and E7 proteins implicated in T cell recognition during HPV infection were not yet well defined because of the usually low frequency of anti-HPV blood $\mathrm{T}$ cell responses and of the difficulties of their study.

In protein E6, some peptides included in, including or overlapping our peptides E6/2 (aa 14-34) and E6/4 (aa 45-68) have already been described as preferentially recognized by 
CD4+ T cells. Among them, peptide E6 42-57 that is restricted by HLA-DR7 has already been identified (Strang et al, 1990). Regions E6 1-31, 22-51 and 24-45 can be also immunogenic for $\mathrm{CD}^{+} \mathrm{T}$ cells as shown in CIN or sexually active healthy women (Kadish et al, 1997). The region E6 42-71, which includes peptide E6/4 (aa 45-68), has also been described as a target of proliferative responses in CIN patients (Kadish et al, 1997). Another E6 111-158 region was previously described as inducing proliferative responses in infected asymptomatic subjects or in patients with CIN3 (Kadish et al, 1997; Strang et al, 1990) as well as E6 127-141 peptide in healthy young women (Gallagher et al, 2007). Similarly, peptides E7 43-77, E7 50-62 and E7 58-68 which are restricted by DR3, DR15 and DR17, respectively, were defined as epitopic peptides for CD4 + T cells (Strang et al, 1990; van der Burg et al, 2001; Wang et al, 2009). E7 region 51-98, including our E7/7 (aa 65-87) peptide, is also very immunogenic for proliferating T lymphocytes (de Gruijl et al, 1998; Luxton et al, 1996; Nakagawa et al, 1996).

The characterization of E6 and E7 HPV-16 epitopes and the HLA restriction of their recognition by CD8+ T lymphocytes are more precise: E6 29-38, E7 11-20, E7 82-90 and E7 86-93 epitopes are presented by HLA-A2 (Evans et al, 2001; Ressing et al, 1995, 1996), E6 8088 and E7 44-52 by HLA-B18 (Bourgault Villada et al, 2000) and E6 49-57 by HLA-A24 (Morishima et al, 2007). In women who cleared HPV 16 infection, cytotoxic T lymphocytes (CTL) responses are directed against epitopes preferentially located in the $\mathrm{N}$-terminal half of the E6 protein (region 16-40) (Nakagawa et al, 2005). In this fragment, the dominant epitope E6 29-37 is restricted by HLA-B48, E6 31-38 by HLA-B4002 and the subdominant epitope E6 52-61 by HLA-B35 (Nakagawa et al, 2007). The same group had also shown that the peptide E6 33-42 61 is recognized by CD8+ T lymphocytes in association with HLA-A68, peptide E6 52-61 in association with HLA-B57 and -B35, peptide E6 75-83 in association with HLA-B62, peptide E7 7-15 in association with HLA-B48 and peptide E7 79-87 in association with HLAB60 (Nakagawa et al, 2004, 2007; Wang et al, 2008). In addition, E7 7-15 is also able to bind HLA-A2 and -B8 to be recognized by CTL (Oerke et al, 2005; Ressing et al, 1995). From the latter results, two hot spots of CD8+ T-cell epitopes in protein E6 may be located in the regions E6 29-38 and 52-61 and another one in protein E7 (E7 7-15) (Nakagawa et al, 2007). Nevertheless, a poor immunogenicity of E7 protein was observed in many studies during both HPV 16 infection and after peptidic vaccination using long peptides spanning both E6 and E7 (Kenter et al, 2008; Welters et al, 2008) such as those used in our study.

The epitopes E6/2 (aa 14-34) and E6/4 (aa 45-68) hence could be strongly recognized by CD4+ and / or CD8+ T lymphocytes and could be particularly relevant in the design of a peptide vaccination. We may hypothesize that the $\mathrm{T}$ cell responses that we observed were able to contain the tumor cells into the epithelium. Therefore, E6/2 (aa 14-34) and E6/4 (aa 45-68) peptides could play a major role in the protection against invasive cancer by stimulating T lymphocytes.

\section{Conclusion}

HPV infections are very frequent. Eighty percent of women more than 25 years old have been infected. Two third of them have been infected by a oncogenic HPV and 10\% of them will develop an intraepithelial neoplasia, mainly CIN. Preventive vaccines are very effective 
means of avoiding CIN and cervical cancer with an efficacy of $70 \%$ against CIN 2/3 related to 14 oncogenic HPVs. Some questions persist about this preventive vaccine: How long will the protection last? Boosts will be necessary? Young boys should be also vaccinated ? What is the best age to perform the vaccine with the highest immunogenicity?

Women previously infected by HPV 16 or 18 and presenting with intraepithelial neoplasia are not good candidate for prophylactic vaccines. Therapeutic vaccines should be good alternatives to surgery for CIN2/3, VIN3 and AIN3 and they are being continuously improved.

\section{References}

Abramowitz, L., Jacquard, A. C., Jaroud, F., Haesebaert, J., Siproudhis, L., Pradat, P., Aynaud, O., Leocmach, Y., Soubeyrand, B., Dachez, R., Riethmuller, D., Mougin, C., Pretet, J. L., \& Denis, F. (2011). Human papillomavirus genotype distribution in anal cancer in France: The EDiTH V study. Int J Cancer 129:433-9.

Af Geijersstam, V., Kibur, M., Wang, Z., Koskela, P., Pukkala, E., Schiller, J., Lehtinen, M., \& Dillner, J. (1998). Stability over time of serum antibody levels to human papillomavirus type 16. J Infect Dis 177:1710-4.

Albarran, Y. C. A., De La Garza, A., Cruz Quiroz, B. J., Vazquez Zea, E., Diaz Estrada, I., Mendez Fuentez, E., Lopez Contreras, M., Andrade-Manzano, A., Padilla, S., Varela, A. R., \& Rosales, R. (2007). MVA E2 recombinant vaccine in the treatment of human papillomavirus infection in men presenting intraurethral flat condyloma: a phase I/II study. BioDrugs 21:47-59.

Arends, M. J., Benton, E. C., Mclaren, K. M., Stark, L. A., Hunter, J. A., \& Bird, C. C. (1997). Renal allograft recipients with high susceptibility to cutaneous malignancy have an increased prevalence of human papillomavirus DNA in skin tumours and a greater risk of anogenital malignancy. Br J Cancer 75:722-8.

Bard, E., Riethmuller, D., Meillet, D., Pretet, J.L., Schaal, J.P., Mougin, C., \& Seilles, E. (2004); High-risk papillomavirus infection is associated with altered antibody responses in genital tract: non-specific responses in HPV infection. Viral Immunol 17:381-9.

Berumen, J., Casas, L., Segura, E., Amezcua, J. L., \& Garcia-Carranca, A. (1994). Genome amplification of human papillomavirus types 16 and 18 in cervical carcinomas is related to the retention of E1/E2 genes. Int J Cancer 56:640-5.

Bosch, F. X., Manos, M. M., Munoz, N., Sherman, M., Jansen, A. M., Peto, J., Schiffman, M. H., Moreno, V., Kurman, R., \& Shah, K. V. (1995). Prevalence of human papillomavirus in cervical cancer: a worldwide perspective. International biological study on cervical cancer (IBSCC) Study Group. J Natl Cancer Inst 87:796-802.

Boulanger, J. C., Sevestre, H., Bauville, E., Ghighi, C., Harlicot, J. P., \& Gondry, J. (2004). [Epidemiology of HPV infection]. Gynecol Obstet Fertil 32:218-23.

Bourgault Villada, I., Beneton, N., Bony, C., Connan, F., Monsonego, J., Bianchi, A., Saiag, P., Levy, J. P., Guillet, J. G., \& Choppin, J. (2000). Identification in humans of HPV-16 E6 and E7 protein epitopes recognized by cytolytic T lymphocytes in association with HLA-B18 and determination of the HLA-B18-specific binding motif. Eur J Immunol 30:2281-9. 
Bourgault Villada, I., Moyal Barracco, M., Ziol, M., Chaboissier, A., Barget, N., Berville, S., Paniel, B., Jullian, E., Clerici, T., Maillere, B., \& Guillet, J. G. (2004). Spontaneous regression of grade 3 vulvar intraepithelial neoplasia associated with human papillomavirus-16-specific $\mathrm{CD} 4(+)$ and $\mathrm{CD} 8(+)$ T-cell responses. Cancer Res 64:8761-6.

Bourgault Villada, I. (2010a). Vaccination against HPV-16 for vulvar intraepithelial neoplasia. N Engl J Med 362:655-6.

Bourgault Villada, I., Moyal Barracco, M., Berville, S., Bafounta, M. L., Longvert, C., Premel, V., Villefroy, P., Jullian, E., Clerici, T., Paniel, B., Maillere, B., Choppin, J., \& Guillet, J. G. (2010b). Human papillomavirus 16-specific T cell responses in classic HPVrelated vulvar intra-epithelial neoplasia. Determination of strongly immunogenic regions from E6 and E7 proteins. Clin Exp Immunol 159:45-56.

Bousarghin, L., Hubert, P., Franzen, E., Jacobs, N., Boniver, J., \& Delvenne, P. (2005). Human papillomavirus 16 virus-like particles use heparan sulfates to bind dendritic cells and colocalize with langerin in Langerhans cells. J Gen Virol 86:1297-305.

Buckley, J. D., Harris, R. W., Doll, R., Vessey, M. P., \& Williams, P. T. (1981). Case-control study of the husbands of women with dysplasia or carcinoma of the cervix uteri. Lancet 2:1010-5.

Carter, J. J., Koutsky, L. A., Hughes, J. P., Lee, S. K., Kuypers, J., Kiviat, N., \& Galloway, D. A. (2000). Comparison of human papillomavirus types 16, 18, and 6 capsid antibody responses following incident infection. J Infect Dis 181:1911-9.

Collins, S. I., Constandinou-Williams, C., Wen, K., Young, L. S., Roberts, S., Murray, P. G., \& Woodman, C. B. (2009). Disruption of the E2 gene is a common and early event in the natural history of cervical human papillomavirus infection: a longitudinal cohort study. Cancer Res 69:3828-32.

Combadiere, B., \& Mahe, B. (2008). Particle-based vaccines for transcutaneous vaccination. Comp Immunol Microbiol Infect Dis 31:293-315.

Conway, M. J., Cruz, L., Alam, S., Christensen, N. D., \& Meyers, C. (2011). Crossneutralization potential of native human papillomavirus $\mathrm{N}$-terminal L2 epitopes. PLoS One 6:e16405.

Daayana, S., Elkord, E., Winters, U., Pawlita, M., Roden, R., Stern, P. L., \& Kitchener, H. C. (2010). Phase II trial of imiquimod and HPV therapeutic vaccination in patients with vulval intraepithelial neoplasia. Br J Cancer 102:1129-36.

Davidson, E. J., Boswell, C. M., Sehr, P., Pawlita, M., Tomlinson, A. E., Mcvey, R. J., Dobson, J., Roberts, J. S., Hickling, J., Kitchener, H. C., \& Stern, P. L. (2003). Immunological and clinical responses in women with vulval intraepithelial neoplasia vaccinated with a vaccinia virus encoding human papillomavirus 16/18 oncoproteins. Cancer Res 63:6032-41.

Day, P. M., Thompson, C. D., Buck, C. B., Pang, Y. Y., Lowy, D. R., \& Schiller, J. T. (2007). Neutralization of human papillomavirus with monoclonal antibodies reveals different mechanisms of inhibition. J Virol 81:8784-92.

De Gruijl, T. D., Bontkes, H. J., Walboomers, J. M., Stukart, M. J., Doekhie, F. S., Remmink, A. J., Helmerhorst, T. J., Verheijen, R. H., Duggan-Keen, M. F., Stern, P. L., Meijer, C. J., \& Scheper, R. J. (1998). Differential T helper cell responses to human 
papillomavirus type $16 \mathrm{E} 7$ related to viral clearance or persistence in patients with cervical neoplasia: a longitudinal study. Cancer Res 58:1700-6.

De Gruijl, T. D., Bontkes, H. J., Walboomers, J. M., Coursaget, P., Stukart, M. J., Dupuy, C., Kueter, E., Verheijen, R. H., Helmerhorst, T. J., Duggan-Keen, M. F., Stern, P. L., Meijer, C. J., \& Scheper, R. J. (1999). Immune responses against human papillomavirus (HPV) type 16 virus-like particles in a cohort study of women with cervical intraepithelial neoplasia. I. Differential T-helper and IgG responses in relation to HPV infection and disease outcome. J Gen Virol 80 ( Pt 2):399-408.

De Jong, A., Van Der Burg, S. H., Kwappenberg, K. M., Van Der Hulst, J. M., Franken, K. L., Geluk, A., Van Meijgaarden, K. E., Drijfhout, J. W., Kenter, G., Vermeij, P., Melief, C. J., \& Offringa, R. (2002). Frequent detection of human papillomavirus 16 E2specific T-helper immunity in healthy subjects. Cancer Res 62:472-9.

De Jong, A., Van Poelgeest, M. I., Van Der Hulst, J. M., Drijfhout, J. W., Fleuren, G. J., Melief, C. J., Kenter, G., Offringa, R., \& Van Der Burg, S. H. (2004). Human papillomavirus type 16-positive cervical cancer is associated with impaired CD4+ T-cell immunity against early antigens E2 and E6. Cancer Res 64:5449-55.

Desaintes, C., \& Demeret, C. (1996). Control of papillomavirus DNA replication and transcription. Semin Cancer Biol 7:339-47.

Dillon, S., Sasagawa, T., Crawford, A., Prestidge, J., Inder, M. K., Jerram, J., Mercer, A. A., \& Hibma, M. (2007). Resolution of cervical dysplasia is associated with T-cell proliferative responses to human papillomavirus type 16 E2. J Gen Virol 88:803-13.

Evans, M., Borysiewicz, L. K., Evans, A. S., Rowe, M., Jones, M., Gileadi, U., Cerundolo, V., \& Man, S. (2001). Antigen processing defects in cervical carcinomas limit the presentation of a CTL epitope from human papillomavirus 16 E6. J Immunol 167:5420-8.

Fausch, S. C., Da Silva, D. M., \& Kast, W. M. (2005). Heterologous papillomavirus virus-like particles and human papillomavirus virus-like particle immune complexes activate human Langerhans cells. Vaccine 23:1720-9.

Gallagher, K. M., \& Man, S. (2007). Identification of HLA-DR1- and HLA-DR15-restricted human papillomavirus type 16 (HPV16) and HPV18 E6 epitopes recognized by CD4+ T cells from healthy young women. J Gen Virol 88:1470-8.

Garcia, F., Petry, K. U., Muderspach, L., Gold, M. A., Braly, P., Crum, C. P., Magill, M., Silverman, M., Urban, R. G., Hedley, M. L., \& Beach, K. J. (2004). ZYC101a for treatment of high-grade cervical intraepithelial neoplasia: a randomized controlled trial. Obstet Gynecol 103:317-26.

Garcia-Hernandez, E., Gonzalez-Sanchez, J. L., Andrade-Manzano, A., Contreras, M. L., Padilla, S., Guzman, C. C., Jimenez, R., Reyes, L., Morosoli, G., Verde, M. L., \& Rosales, R. (2006). Regression of papilloma high-grade lesions (CIN 2 and CIN 3) is stimulated by therapeutic vaccination with MVA E2 recombinant vaccine. Cancer Gene Ther 13:592-7.

Garland, S. M., Hernandez-Avila, M., Wheeler, C. M., Perez, G., Harper, D. M., Leodolter, S., Tang, G. W., Ferris, D. G., Steben, M., Bryan, J., Taddeo, F. J., Railkar, R., Esser, M. T., Sings, H. L., Nelson, M., Boslego, J., Sattler, C., Barr, E., \& Koutsky, L. A. (2007). Quadrivalent vaccine against human papillomavirus to prevent anogenital diseases. N Engl J Med 356:1928-43. 
Giraldo, P. C., Eleuterio, J., Jr., Cavalcante, D. I., Goncalves, A. K., Romao, J. A., \& Eleuterio, R. M. (2008). The role of high-risk HPV-DNA testing in the male sexual partners of women with HPV-induced lesions. Eur J Obstet Gynecol Reprod Biol 137:88-91.

Giuliano, A. R., Palefsky, J. M., Goldstone, S., Moreira, E. D., Jr., Penny, M. E., Aranda, C., Vardas, E., Moi, H., Jessen, H., Hillman, R., Chang, Y. H., Ferris, D., Rouleau, D., Bryan, J., Marshall, J. B., Vuocolo, S., Barr, E., Radley, D., Haupt, R. M., \& Guris, D. (2011). Efficacy of quadrivalent HPV vaccine against HPV Infection and disease in males. N Engl J Med 364:401-11.

Grover, A., Kim, G. J., Lizee, G., Tschoi, M., Wang, G., Wunderlich, J. R., Rosenberg, S. A., Hwang, S. T., \& Hwu, P. (2006). Intralymphatic dendritic cell vaccination induces tumor antigen-specific, skin-homing T lymphocytes. Clin Cancer Res 12:5801-8.

Harper, D. M., Franco, E. L., Wheeler, C., Ferris, D. G., Jenkins, D., Schuind, A., Zahaf, T., Innis, B., Naud, P., De Carvalho, N. S., Roteli-Martins, C. M., Teixeira, J., Blatter, M. M., Korn, A. P., Quint, W., \& Dubin, G. (2004). Efficacy of a bivalent L1 virus-like particle vaccine in prevention of infection with human papillomavirus types 16 and 18 in young women: a randomised controlled trial. Lancet 364:1757-65.

Harper, D. M., Franco, E. L., Wheeler, C. M., Moscicki, A. B., Romanowski, B., RoteliMartins, C. M., Jenkins, D., Schuind, A., Costa Clemens, S. A., \& Dubin, G. (2006). Sustained efficacy up to 4.5 years of a bivalent L1 virus-like particle vaccine against human papillomavirus types 16 and 18: follow-up from a randomised control trial. Lancet 367:1247-55.

Harro, C. D., Pang, Y. Y., Roden, R. B., Hildesheim, A., Wang, Z., Reynolds, M. J., Mast, T. C., Robinson, R., Murphy, B. R., Karron, R. A., Dillner, J., Schiller, J. T., \& Lowy, D. R. (2001). Safety and immunogenicity trial in adult volunteers of a human papillomavirus 16 L1 virus-like particle vaccine. J Natl Cancer Inst 93:284-92.

Herbst, B., Kohler, G., Mackensen, A., Veelken, H., Kulmburg, P., Rosenthal, F. M., Schaefer, H. E., Mertelsmann, R., Fisch, P., \& Lindemann, A. (1996). In vitro differentiation of CD34+ hematopoietic progenitor cells toward distinct dendritic cell subsets of the birbeck granule and MIIC-positive Langerhans cell and the interdigitating dendritic cell type. Blood 88:2541-8.

Hippelainen, M. I., Yliskoski, M., Syrjanen, S., Saastamoinen, J., Hippelainen, M., Saarikoski, S., \& Syrjanen, K. (1994). Low concordance of genital human papillomavirus (HPV) lesions and viral types in HPV-infected women and their male sexual partners. Sex Transm Dis 21:76-82.

Ho, G. Y., Studentsov, Y. Y., Bierman, R., \& Burk, R. D. (2004). Natural history of human papillomavirus type 16 virus-like particle antibodies in young women. Cancer Epidemiol Biomarkers Prev 13:110-6.

Jacobelli S., Sanaa. F.., Moyal Barracco M., Pelisse M., Berville S., Villefroy P., North M.O., Figueiredo S., Charmeteau B., Clerici T., Plantier F., Dupin N., Avril M.F., Guillet J.G., \& Bourgault Villada I. (2011). Anti-HPV16 E2 protein T-cell responses and viral control in women with usual vulvar intraepithelial neoplasia and their healthy partners. Submitted.

Joura, E. A., Leodolter, S., Hernandez-Avila, M., Wheeler, C. M., Perez, G., Koutsky, L. A., Garland, S. M., Harper, D. M., Tang, G. W., Ferris, D. G., Steben, M., Jones, R. W., Bryan, J., Taddeo, F. J., Bautista, O. M., Esser, M. T., Sings, H. L., Nelson, M., 
Boslego, J. W., Sattler, C., Barr, E., \& Paavonen, J. (2007). Efficacy of a quadrivalent prophylactic human papillomavirus (types 6, 11, 16, and 18) L1 virus-like-particle vaccine against high-grade vulval and vaginal lesions: a combined analysis of three randomised clinical trials. Lancet 369:1693-702.

Kadish, A. S., Ho, G. Y., Burk, R. D., Wang, Y., Romney, S. L., Ledwidge, R., \& Angeletti, R. H. (1997). Lymphoproliferative responses to human papillomavirus (HPV) type 16 proteins E6 and E7: outcome of HPV infection and associated neoplasia. J Natl Cancer Inst 89:1285-93.

Kenter, G. G., Welters, M. J., Valentijn, A. R., Lowik, M. J., Berends-Van Der Meer, D. M., Vloon, A. P., Drijfhout, J. W., Wafelman, A. R., Oostendorp, J., Fleuren, G. J., Offringa, R., Van Der Burg, S. H., \& Melief, C. J. (2008). Phase I immunotherapeutic trial with long peptides spanning the E6 and E7 sequences of high-risk human papillomavirus 16 in end-stage cervical cancer patients shows low toxicity and robust immunogenicity. Clin Cancer Res 14:169-77.

Kenter, G. G., Welters, M. J., Valentijn, A. R., Lowik, M. J., Berends-Van Der Meer, D. M., Vloon, A. P., Essahsah, F., Fathers, L. M., Offringa, R., Drijfhout, J. W., Wafelman, A. R., Oostendorp, J., Fleuren, G. J., Van Der Burg, S. H., \& Melief, C. J. (2009). Vaccination against HPV-16 oncoproteins for vulvar intraepithelial neoplasia. $N$ Engl J Med 361:1838-47.

Kines, R. C., Thompson, C. D., Lowy, D. R., Schiller, J. T., \& Day, P. M. (2009). The initial steps leading to papillomavirus infection occur on the basement membrane prior to cell surface binding. Proc Natl Acad Sci U S A 106:20458-63.

Kirnbauer, R., Hubbert, N. L., Wheeler, C. M., Becker, T. M., Lowy, D. R., \& Schiller, J. T. (1994). A virus-like particle enzyme-linked immunosorbent assay detects serum antibodies in a majority of women infected with human papillomavirus type $16 . J$ Natl Cancer Inst 86:494-9.

Koutsky, L. A., Ault, K. A., Wheeler, C. M., Brown, D. R., Barr, E., Alvarez, F. B., Chiacchierini, L. M., \& Jansen, K. U. (2002). A controlled trial of a human papillomavirus type 16 vaccine. N Engl J Med 347:1645-51.

Lacey, C. J., Thompson, H. S., Monteiro, E. F., O'neill, T., Davies, M. L., Holding, F. P., Fallon, R. E., \& Roberts, J. S. (1999). Phase IIa safety and immunogenicity of a therapeutic vaccine, TA-GW, in persons with genital warts. J Infect Dis 179:612-8.

Lawrence, T., Puel, A., Reichenbach, J., Ku, C. L., Chapgier, A., Renner, E., Minard-Colin, V., Ouachee, M., \& Casanova, J. L. (2005). Autosomal-dominant primary immunodeficiencies. Curr Opin Hematol 12:22-30.

Lowe, R. S., Brown, D. R., Bryan, J. T., Cook, J. C., George, H. A., Hofmann, K. J., Hurni, W. M., Joyce, J. G., Lehman, E. D., Markus, H. Z., Neeper, M. P., Schultz, L. D., Shaw, A. R., \& Jansen, K. U. (1997). Human papillomavirus type 11 (HPV-11) neutralizing antibodies in the serum and genital mucosal secretions of African green monkeys immunized with HPV-11 virus-like particles expressed in yeast. I Infect Dis 176:1141-5.

Luxton, J. C., Rowe, A. J., Cridland, J. C., Coletart, T., Wilson, P., \& Shepherd, P. S. (1996). Proliferative $\mathrm{T}$ cell responses to the human papillomavirus type 16 E7 protein in women with cervical dysplasia and cervical carcinoma and in healthy individuals. J Gen Virol 77 ( Pt 7):1585-93. 
Malejczyk, J., Majewski, S., \& Jablonska, S. (1997). Cellular immunity in cutaneous and genital HPV infections. Clin Dermatol 15:261-74.

Matthews, K., Leong, C. M., Baxter, L., Inglis, E., Yun, K., Backstrom, B. T., Doorbar, J., \& Hibma, M. (2003). Depletion of Langerhans cells in human papillomavirus type 16infected skin is associated with E6-mediated down regulation of E-cadherin. J Virol 77:8378-85.

McCluggage, W. G. (2009). Recent developments in vulvovaginal pathology. Histopathology 54:156-73.

McCredie, M. R., Sharples, K. J., Paul, C., Baranyai, J., Medley, G., Jones, R. W., \& Skegg, D. C. (2008). Natural history of cervical neoplasia and risk of invasive cancer in women with cervical intraepithelial neoplasia 3: a retrospective cohort study. Lancet Oncol 9:425-34.

McKeage, K., \& Romanowski, B. (2011). AS04-adjuvanted human papillomavirus (HPV) types 16 and 18 vaccine (Cervarix $(R)$ ): a review of its use in the prevention of premalignant cervical lesions and cervical cancer causally related to certain oncogenic HPV types. Drugs 71:465-88.

Molling, J. W., De Gruijl, T. D., Glim, J., Moreno, M., Rozendaal, L., Meijer, C. J., Van Den Eertwegh, A. J., Scheper, R. J., Von Blomberg, M. E., \& Bontkes, H. J. (2007). CD4(+)CD25hi regulatory T-cell frequency correlates with persistence of human papillomavirus type 16 and $\mathrm{T}$ helper cell responses in patients with cervical intraepithelial neoplasia. Int J Cancer 121:1749-55.

Morishima, S., Akatsuka, Y., Nawa, A., Kondo, E., Kiyono, T., Torikai, H., Nakanishi, T., Ito, Y., Tsujimura, K., Iwata, K., Ito, K., Kodera, Y., Morishima, Y., Kuzushima, K., \& Takahashi, T. (2007). Identification of an HLA-A24-restricted cytotoxic T lymphocyte epitope from human papillomavirus type-16 E6: the combined effects of bortezomib and interferon-gamma on the presentation of a cryptic epitope. Int J Cancer 120:594-604.

Muderspach, L., Wilczynski, S., Roman, L., Bade, L., Felix, J., Small, L. A., Kast, W. M., Fascio, G., Marty, V., \& Weber, J. (2000). A phase I trial of a human papillomavirus (HPV) peptide vaccine for women with high-grade cervical and vulvar intraepithelial neoplasia who are HPV 16 positive. Clin Cancer Res 6:3406-16.

Munoz, N., Kjaer, S. K., Sigurdsson, K., Iversen, O. E., Hernandez-Avila, M., Wheeler, C. M., Perez, G., Brown, D. R., Koutsky, L. A., Tay, E. H., Garcia, P. J., Ault, K. A., Garland, S. M., Leodolter, S., Olsson, S. E., Tang, G. W., Ferris, D. G., Paavonen, J., Steben, M., Bosch, F. X., Dillner, J., Huh, W. K., Joura, E. A., Kurman, R. J., Majewski, S., Myers, E. R., Villa, L. L., Taddeo, F. J., Roberts, C., Tadesse, A., Bryan, J. T., Lupinacci, L. C., Giacoletti, K. E., Sings, H. L., James, M. K., Hesley, T. M., Barr, E., \& Haupt, R. M. (2010). Impact of human papillomavirus (HPV)$6 / 11 / 16 / 18$ vaccine on all HPV-associated genital diseases in young women. J Natl Cancer Inst 102:325-39.

Nakagawa, M., Stites, D. P., Farhat, S., Judd, A., Moscicki, A. B., Canchola, A. J., Hilton, J. F., \& Palefsky, J. M. (1996). T-cell proliferative response to human papillomavirus type 16 peptides: relationship to cervical intraepithelial neoplasia. Clin Diagn Lab Immunol 3:205-10. 
Nakagawa, M., Stites, D. P., Farhat, S., Sisler, J. R., Moss, B., Kong, F., Moscicki, A. B., \& Palefsky, J. M. (1997). Cytotoxic T lymphocyte responses to E6 and E7 proteins of human papillomavirus type 16: relationship to cervical intraepithelial neoplasia. J Infect Dis 175:927-31.

Nakagawa, M., Stites, D. P., Patel, S., Farhat, S., Scott, M., Hills, N. K., Palefsky, J. M., \& Moscicki, A. B. (2000). Persistence of human papillomavirus type 16 infection is associated with lack of cytotoxic T lymphocyte response to the E6 antigens. J Infect Dis 182:595-8.

Nakagawa, M., Kim, K. H., \& Moscicki, A. B. (2004). Different methods of identifying new antigenic epitopes of human papillomavirus type 16 E6 and E7 proteins. Clin Diagn Lab Immunol 11:889-96.

Nakagawa, M., Kim, K. H., \& Moscicki, A. B. (2005). Patterns of CD8 T-cell epitopes within the human papillomavirus type 16 (HPV 16) E6 protein among young women whose HPV 16 infection has become undetectable. Clin Diagn Lab Immunol 12:10035.

Nakagawa, M., Kim, K. H., Gillam, T. M., \& Moscicki, A. B. (2007). HLA class I binding promiscuity of the CD8 T-cell epitopes of human papillomavirus type 16 E6 protein. J Virol 81:1412-23.

Nardelli-Haefliger, D., Wirthner, D., Schiller, J. T., Lowy, D. R., Hildesheim, A., Ponci, F., \& De Grandi, P. (2003). Specific antibody levels at the cervix during the menstrual cycle of women vaccinated with human papillomavirus 16 virus-like particles. $J$ Natl Cancer Inst 95:1128-37.

Nicolau, S. M., Camargo, C. G., Stavale, J. N., Castelo, A., Dores, G. B., Lorincz, A., \& De Lima, G. R. (2005). Human papillomavirus DNA detection in male sexual partners of women with genital human papillomavirus infection. Urology 65:251-5.

Oerke, S., Hohn, H., Zehbe, I., Pilch, H., Schicketanz, K. H., Hitzler, W. E., Neukirch, C., Freitag, K., \& Maeurer, M. J. (2005). Naturally processed and HLA-B8-presented HPV16 E7 epitope recognized by $\mathrm{T}$ cells from patients with cervical cancer. Int J Cancer 114:766-78.

Offringa, R., De Jong, A., Toes, R. E., Van Der Burg, S. H., \& Melief, C. J. (2003). Interplay between human papillomaviruses and dendritic cells. Curr Top Microbiol Immunol 276:215-40.

Ostor, A. G. (1993). Natural history of cervical intraepithelial neoplasia: a critical review. Int J Gynecol Pathol 12:186-92.

Paavonen, J., Jenkins, D., Bosch, F. X., Naud, P., Salmeron, J., Wheeler, C. M., Chow, S. N., Apter, D. L., Kitchener, H. C., Castellsague, X., De Carvalho, N. S., Skinner, S. R., Harper, D. M., Hedrick, J. A., Jaisamrarn, U., Limson, G. A., Dionne, M., Quint, W., Spiessens, B., Peeters, P., Struyf, F., Wieting, S. L., Lehtinen, M. O., \& Dubin, G. (2007). Efficacy of a prophylactic adjuvanted bivalent L1 virus-like-particle vaccine against infection with human papillomavirus types 16 and 18 in young women: an interim analysis of a phase III double-blind, randomised controlled trial. Lancet 369:2161-70.

Paavonen, J., Naud, P., Salmeron, J., Wheeler, C. M., Chow, S. N., Apter, D., Kitchener, H., Castellsague, X., Teixeira, J. C., Skinner, S. R., Hedrick, J., Jaisamrarn, U., Limson, G., Garland, S., Szarewski, A., Romanowski, B., Aoki, F. Y., Schwarz, T. F., Poppe, 
W. A., Bosch, F. X., Jenkins, D., Hardt, K., Zahaf, T., Descamps, D., Struyf, F., Lehtinen, M., Dubin, G., \& Greenacre, M. (2009). Efficacy of human papillomavirus (HPV)-16/18 AS04-adjuvanted vaccine against cervical infection and precancer caused by oncogenic HPV types (PATRICIA): final analysis of a double-blind, randomised study in young women. Lancet 374:301-14.

Palefsky, J. M., Berry, J. M., Jay, N., Krogstad, M., Da Costa, M., Darragh, T. M., \& Lee, J. Y. (2006). A trial of SGN-00101 (HspE7) to treat high-grade anal intraepithelial neoplasia in HIV-positive individuals. Aids 20:1151-5.

Palucka, K., Ueno, H., Roberts, L., Fay, J., \& Banchereau, J. (2010). Dendritic cell subsets as vectors and targets for improved cancer therapy. Curr Top Microbiol Immunol 344:173-92.

Patel, S., \& Chiplunkar, S. (2009). Host immune responses to cervical cancer. Curr Opin Obstet Gynecol 21:54-9.

Piketty, C., Selinger-Leneman, H., Grabar, S., Duvivier, C., Bonmarchand, M., Abramowitz, L., Costagliola, D., \& Mary-Krause, M. (2008). Marked increase in the incidence of invasive anal cancer among HIV-infected patients despite treatment with combination antiretroviral therapy. Aids 22:1203-11.

Piketty C, A. S.-M., E. Lanoy, B. Cochand-Priollet, S. Trabelsi, P-M. Girard, R. Tubiana, L. Abramowitz, E. Tartour, L. Weiss, D. Costagliola, \& the Valparaiso Study Group. (2010). Lack of regression of anal squamous intraepithelial lesions and anal HPV infection despite immune restoration under cART. 18th International AIDS Conference.

Reiter, P. L., Pendergraft, W. F., 3rd, \& Brewer, N. T. (2010). Meta-analysis of human papillomavirus infection concordance. Cancer Epidemiol Biomarkers Prev 19:2916-31.

Ressing, M. E., Sette, A., Brandt, R. M., Ruppert, J., Wentworth, P. A., Hartman, M., Oseroff, C., Grey, H. M., Melief, C. J., \& Kast, W. M. (1995). Human CTL epitopes encoded by human papillomavirus type $16 \mathrm{E} 6$ and E7 identified through in vivo and in vitro immunogenicity studies of HLA-A*0201-binding peptides. J Immunol 154:5934-43.

Ressing, M. E., Van Driel, W. J., Celis, E., Sette, A., Brandt, M. P., Hartman, M., Anholts, J. D., Schreuder, G. M., Ter Harmsel, W. B., Fleuren, G. J., Trimbos, B. J., Kast, W. M., \& Melief, C. J. (1996). Occasional memory cytotoxic T-cell responses of patients with human papillomavirus type 16-positive cervical lesions against a human leukocyte antigen-A *0201-restricted E7-encoded epitope. Cancer Res 56:582-8.

Ressing, M. E., Van Driel, W. J., Brandt, R. M., Kenter, G. G., De Jong, J. H., Bauknecht, T., Fleuren, G. J., Hoogerhout, P., Offringa, R., Sette, A., Celis, E., Grey, H., Trimbos, B. J., Kast, W. M., \& Melief, C. J. (2000). Detection of T helper responses, but not of human papillomavirus-specific cytotoxic $\mathrm{T}$ lymphocyte responses, after peptide vaccination of patients with cervical carcinoma. J Immunother 23:255-66.

Santin, A. D., Bellone, S., Palmieri, M., Zanolini, A., Ravaggi, A., Siegel, E. R., Roman, J. J., Pecorelli, S., \& Cannon, M. J. (2008). Human papillomavirus type 16 and 18 E7pulsed dendritic cell vaccination of stage IB or IIA cervical cancer patients: a phase I escalating-dose trial. J Virol 82:1968-79.

Sapp, M., \& Bienkowska-Haba, M. (2009). Viral entry mechanisms: human papillomavirus and a long journey from extracellular matrix to the nucleus. Febs J 276:7206-16. 
Sauzet, J. P., Deprez, B., Martinon, F., Guillet, J. G., Gras-Masse, H., \& Gomard, E. (1995). Long-lasting anti-viral cytotoxic $\mathrm{T}$ lymphocytes induced in vivo with chimericmultirestricted lipopeptides. Vaccine 13:1339-45.

Schellenbacher, C., Roden, R., \& Kirnbauer, R. (2009). Chimeric L1-L2 virus-like particles as potential broad-spectrum human papillomavirus vaccines. J Virol 83:10085-95.

Srodon, M., Stoler, M. H., Baber, G. B., \& Kurman, R. J. (2006). The distribution of low and high-risk HPV types in vulvar and vaginal intraepithelial neoplasia (VIN and VaIN). Am J Surg Pathol 30:1513-8.

Steller, M. A., Gurski, K. J., Murakami, M., Daniel, R. W., Shah, K. V., Celis, E., Sette, A., Trimble, E. L., Park, R. C., \& Marincola, F. M. (1998). Cell-mediated immunological responses in cervical and vaginal cancer patients immunized with a lipidated epitope of human papillomavirus type 16 E7. Clin Cancer Res 4:2103-9.

Strang, G., Hickling, J. K., Mcindoe, G. A., Howland, K., Wilkinson, D., Ikeda, H., \& Rothbard, J. B. (1990). Human T cell responses to human papillomavirus type 16 L1 and E6 synthetic peptides: identification of T cell determinants, HLA-DR restriction and virus type specificity. J Gen Virol 71 ( Pt 2):423-31.

Sun, X. W., Kuhn, L., Ellerbrock, T. V., Chiasson, M. A., Bush, T. J., \& Wright, T. C., Jr. (1997). Human papillomavirus infection in women infected with the human immunodeficiency virus. N Engl J Med 337:1343-9.

Thompson, H. S., Davies, M. L., Holding, F. P., Fallon, R. E., Mann, A. E., O'neill, T., \& Roberts, J. S. (1999). Phase I safety and antigenicity of TA-GW: a recombinant HPV6 L2E7 vaccine for the treatment of genital warts. Vaccine 17:40-9.

Tsukui, T., Hildesheim, A., Schiffman, M. H., Lucci, J., 3rd, Contois, D., Lawler, P., Rush, B. B., Lorincz, A. T., Corrigan, A., Burk, R. D., Qu, W., Marshall, M. A., Mann, D., Carrington, M., Clerici, M., Shearer, G. M., Carbone, D. P., Scott, D. R., Houghten, R. A., \& Berzofsky, J. A. (1996). Interleukin 2 production in vitro by peripheral lymphocytes in response to human papillomavirus-derived peptides: correlation with cervical pathology. Cancer Res 56:3967-74.

Ulrich, C., Hackethal, M., Meyer, T., Geusau, A., Nindl, I., Ulrich, M., Forschner, T., Sterry, W., \& Stockfleth, E. (2008). Skin infections in organ transplant recipients. J Dtsch Dermatol Ges 6:98-105.

Van Der Burg, S. H., Ressing, M. E., Kwappenberg, K. M., De Jong, A., Straathof, K., De Jong, J., Geluk, A., Van Meijgaarden, K. E., Franken, K. L., Ottenhoff, T. H., Fleuren, G. J., Kenter, G., Melief, C. J., \& Offringa, R. (2001). Natural T-helper immunity against human papillomavirus type 16 (HPV16) E7-derived peptide epitopes in patients with HPV16-positive cervical lesions: identification of 3 human leukocyte antigen class II-restricted epitopes. Int J Cancer 91:612-8.

Van Der Burg, S. H., Piersma, S. J., De Jong, A., Van Der Hulst, J. M., Kwappenberg, K. M., Van Den Hende, M., Welters, M. J., Van Rood, J. J., Fleuren, G. J., Melief, C. J., Kenter, G. G., \& Offringa, R. (2007). Association of cervical cancer with the presence of CD4+ regulatory $\mathrm{T}$ cells specific for human papillomavirus antigens. Proc Natl Acad Sci U S A 104:12087-92.

Van Driel, W. J., Ressing, M. E., Kenter, G. G., Brandt, R. M., Krul, E. J., Van Rossum, A. B., Schuuring, E., Offringa, R., Bauknecht, T., Tamm-Hermelink, A., Van Dam, P. A., Fleuren, G. J., Kast, W. M., Melief, C. J., \& Trimbos, J. B. (1999). Vaccination with 
HPV16 peptides of patients with advanced cervical carcinoma: clinical evaluation of a phase I-II trial. Eur J Cancer 35:946-52.

Vandepapeliere, P., Barrasso, R., Meijer, C. J., Walboomers, J. M., Wettendorff, M., Stanberry, L. R., \& Lacey, C. J. (2005). Randomized controlled trial of an adjuvanted human papillomavirus (HPV) type 6 L2E7 vaccine: infection of external anogenital warts with multiple HPV types and failure of therapeutic vaccination. J Infect Dis 192:2099-107.

Viscidi, R. P., Schiffman, M., Hildesheim, A., Herrero, R., Castle, P. E., Bratti, M. C., Rodriguez, A. C., Sherman, M. E., Wang, S., Clayman, B., \& Burk, R. D. (2004). Seroreactivity to human papillomavirus (HPV) types 16, 18, or 31 and risk of subsequent HPV infection: results from a population-based study in Costa Rica. Cancer Epidemiol Biomarkers Prev 13:324-7.

Viscidi, R. P., Snyder, B., Cu-Uvin, S., Hogan, J. W., Clayman, B., Klein, R. S., Sobel, J., \& Shah, K. V. (2005). Human papillomavirus capsid antibody response to natural infection and risk of subsequent HPV infection in HIV-positive and HIV-negative women. Cancer Epidemiol Biomarkers Prev 14:283-8.

Visser, J., Nijman, H. W., Hoogenboom, B. N., Jager, P., Van Baarle, D., Schuuring, E., Abdulahad, W., Miedema, F., Van Der Zee, A. G., \& Daemen, T. (2007). Frequencies and role of regulatory $\mathrm{T}$ cells in patients with (pre)malignant cervical neoplasia. Clin Exp Immunol 150:199-209.

Wang, X., Moscicki, A. B., Tsang, L., Brockman, A., \& Nakagawa, M. (2008). Memory T cells specific for novel human papillomavirus type 16 (HPV16) E6 epitopes in women whose HPV16 infection has become undetectable. Clin Vaccine Immunol 15:937-45.

Wang, X., Santin, A. D., Bellone, S., Gupta, S., \& Nakagawa, M. (2009). A novel CD4 T-cell epitope described from one of the cervical cancer patients vaccinated with HPV 16 or 18 E7-pulsed dendritic cells. Cancer Immunol Immunother 58:301-8.

Welters, M. J., Kenter, G. G., Piersma, S. J., Vloon, A. P., Lowik, M. J., Berends-Van Der Meer, D. M., Drijfhout, J. W., Valentijn, A. R., Wafelman, A. R., Oostendorp, J., Fleuren, G. J., Offringa, R., Melief, C. J., \& Van Der Burg, S. H. (2008). Induction of tumor-specific CD4+ and CD8+ T-cell immunity in cervical cancer patients by a human papillomavirus type 16 E6 and E7 long peptides vaccine. Clin Cancer Res 14:178-87.

Xue, Y., Bellanger, S., Zhang, W., Lim, D., Low, J., Lunny, D., \& Thierry, F. (2010). HPV16 E2 is an immediate early marker of viral infection, preceding E7 expression in precursor structures of cervical carcinoma. Cancer Res 70:5316-25.

Yan, M., Peng, J., Jabbar, I. A., Liu, X., Filgueira, L., Frazer, I. H., \& Thomas, R. (2004). Despite differences between dendritic cells and Langerhans cells in the mechanism of papillomavirus-like particle antigen uptake, both cells cross-prime $\mathrm{T}$ cells. Virology 324:297-310.Zehbe, I., Schmidt, M., Maeurer, M., Leo, C., Hockel, M., \& Pilch, H. (2006). Different T-cell receptor (TCR) zeta chain expression in cervical cancer and its precursor lesions. Zentralbl Gynakol 128:266-70.

Zehbe I., Schmidt M., Maeurer M., Leo C., Höckel M., \& Pilch H. (2006). Different T-cell receptor (TCR) zeta chain expression in cervical cancer and its precursor lesions. Zentralbl Gynakol 128:266-70. 

- From Bench to Bedside - A Clinical Perspective

Zhang, L. F., Zhou, J., Chen, S., Cai, L. L., Bao, Q. Y., Zheng, F. Y., Lu, J. Q., Padmanabha, J., Hengst, K., Malcolm, K., \& Frazer, I. H. (2000). HPV6b virus like particles are potent immunogens without adjuvant in man. Vaccine 18:1051-8. 


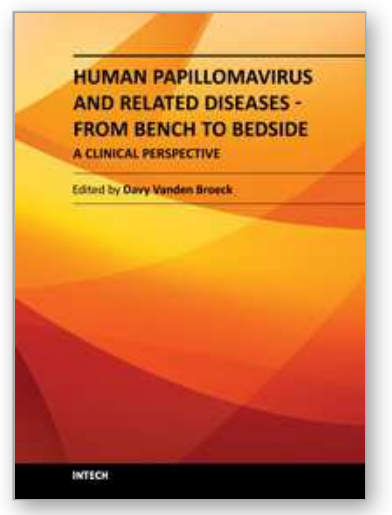

\author{
Human Papillomavirus and Related Diseases - From Bench to \\ Bedside - A Clinical Perspective
}

Edited by Dr. Davy Vanden Broeck

ISBN 978-953-307-860-1

Hard cover, 348 pages

Publisher InTech

Published online 20, January, 2012

Published in print edition January, 2012

Cervical cancer is the second most prevalent cancer among women worldwide, and infection with Human Papilloma Virus (HPV) has been identified as the causal agent for this condition. The natural history of cervical cancer is characterized by slow disease progression, rendering the condition, in essence, preventable and even treatable when diagnosed in early stages. Pap smear and the recently introduced prophylactic vaccines are the most prominent prevention options, but despite the availability of these primary and secondary screening tools, the global burden of disease is unfortunately still very high. This book will focus on the clinical aspects of HPV and related disease, highlighting the latest developments in this field.

\title{
How to reference
}

In order to correctly reference this scholarly work, feel free to copy and paste the following:

Isabelle Bourgault-Villada and Simon Jacobelli (2012). Current Insight into Anti-HPV Immune Responses and Lessons for Prophylactic and Therapeutic Vaccines, Human Papillomavirus and Related Diseases - From Bench to Bedside - A Clinical Perspective, Dr. Davy Vanden Broeck (Ed.), ISBN: 978-953-307-860-1, InTech, Available from: http://www.intechopen.com/books/human-papillomavirus-and-related-diseases-from-bench-tobedside-a-clinical-perspective/current-insight-into-anti-hpv-immune-responses-and-lessons-for-prophylacticand-therapeutic-vaccines

\section{INTECH}

open science | open minds

\author{
InTech Europe \\ University Campus STeP Ri \\ Slavka Krautzeka 83/A \\ 51000 Rijeka, Croatia \\ Phone: +385 (51) 770447 \\ Fax: +385 (51) 686166 \\ www.intechopen.com
}

\author{
InTech China \\ Unit 405, Office Block, Hotel Equatorial Shanghai \\ No.65, Yan An Road (West), Shanghai, 200040, China \\ 中国上海市延安西路65号上海国际贵都大饭店办公楼 405 单元 \\ Phone: +86-21-62489820 \\ Fax: $+86-21-62489821$
}


(C) 2012 The Author(s). Licensee IntechOpen. This is an open access article distributed under the terms of the Creative Commons Attribution 3.0 License, which permits unrestricted use, distribution, and reproduction in any medium, provided the original work is properly cited. 